術後27年目に骨転移・肝転移をきたした乳癌の 1 例

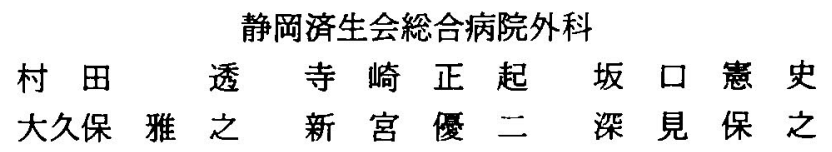

術後27年目に骨転移，肝転移による再発をきたした症例を経験した。患者は69歳，女 性. 主訴は腰痛. 42歳時に左乳癌にて定型的乳房切断術を受けている. 上記主訴にて当 院整形外科を受診し, 腰椎の病的骨折を疑われCT 下骨生検が施行された。病理組織診 断て腺癌の骨転移と診断され, 婦人科, 消化器内科で原発巣の検索がされた後, 当科に コンサルトされた。生検材料の免疫染色にて ER 陽性であり,27年前の乳癌の晚期転移再 発と診断した. 全身検索の結果, 肝に径 $3 \mathrm{~cm}$ の転移巣も認められた。治療は, 骨転移に 対しては $30 \mathrm{~Gy}$ の放射線照射を行った後, パクリタキセルとアナストロソールによる化 学内分泌療法を施行して，現在 NC の状態である。

索引用語 : 孚癌, 晩期再発

はじめに

乳癌の再発は, 手術例の18～25\%にみられ，そのう 与術後 5 年間に約 $90 \%$ 発症するとされている. しか し術後 20 年以上の長期間を释てから再発をきたす症例 の報告もしばしばみられる，今回われわれは，乳癌術 後27年で骨転移，肝転移をきたした症例を経験したの で報告する。

$$
\text { 症例 }
$$

患者: 69歳, 女性.

主訴: 腰痛.

家族歴：特記すべきことなし。

既往歴：1977年 6 月 (42歳), 左乳癌に対して定型的 乳房切断術が施行された(T1N0M0にて stage I ). 病 理組織診断は, 粘液癌であった(図1)。術後約 5 年間 外来通院されていたが，その後定期受診はしていない.

現病歴: 平成16年 6 月頃より左腰部から左股間にか けて疼痛を訴え, 当院整形外科を受診した。腰椎レン トゲン写真および腰椎 CT にて第 4 腰椎に圧迫骨折を 認め(図 2,3), 病的骨折が疑われ CT 下生検が行わ れた。病理組織診断で腺癌の骨転移と診断された（図 4). 当初卵巣あるいは消化管癌の骨転移が疑われ，産

2005 年 2 月28日受付 2005 年 3 月 30 日採用 〈所属施設住所〉

テ422-8527 静岡市駿河区小当 $1-1-1$
婦人科および消化器内科にコンサルトされ，精查が行 われたが異常所見は認められなかった。ささらに原発巣 の検索のために当科にコンサルトされ，乳癌の既往が あることより骨生検組織の ER, PgR および HER2/ neuの免度組織染色を行ったところ, ERと HER2/ neu が陽性を示した.

現症：左前胸部の乳癌手術創には異常所見はみられ

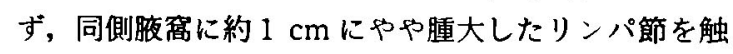
知した（後の吸引細胞診検査の結果は陰性であった）。

当科受診時血液検查所見：血算, 生化学検查では異

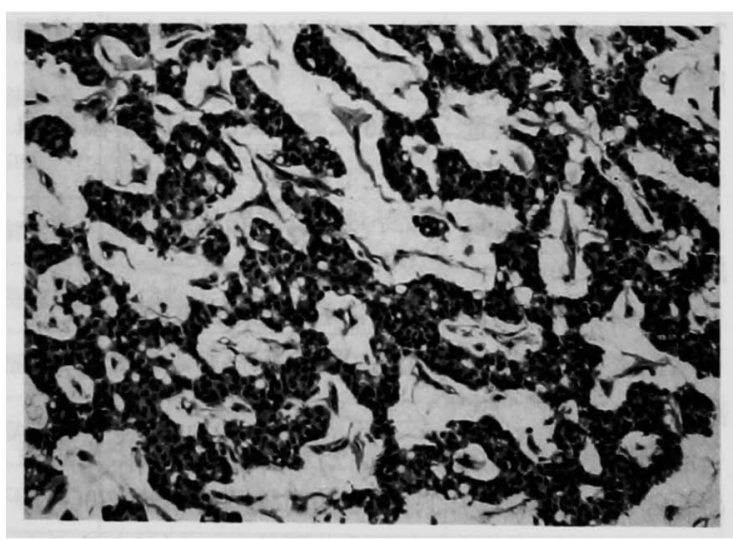

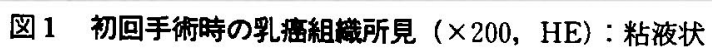
の胞巣の中に痘細胞が不規則に増生しておう, 粘液癌の 所見である、一部管腔状の構造を呈する部分もみられる。 


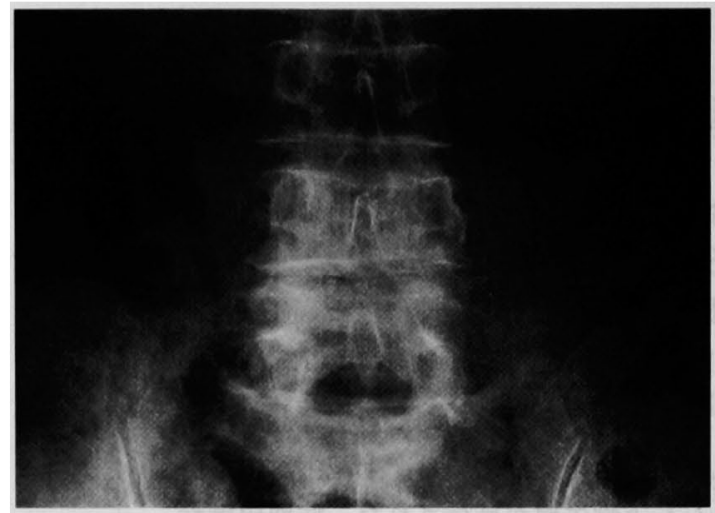

図 2 腰部 $\mathrm{X}$ 線検査：第 4 腰椎の左椎弓根が不明暸であ り，腰椎の圧壤所見を認める。

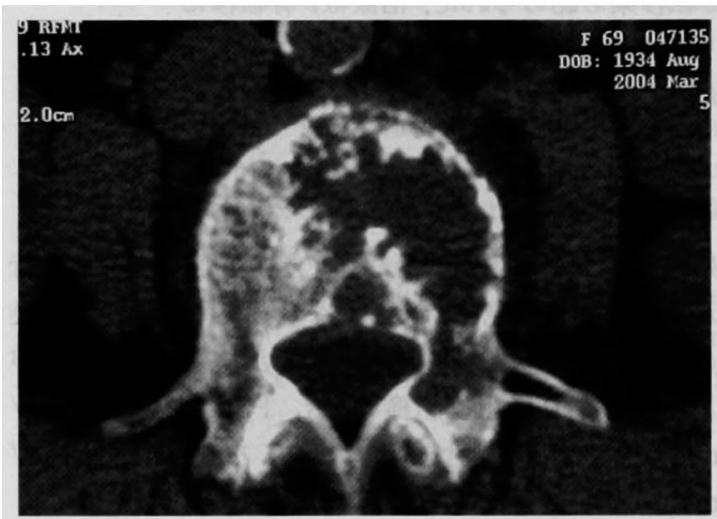

図 3 腰椎 CT 検査: 第 4 腰椎左側で low density area を認め, 骨融解の所見である.

常所見は認めなかった，腫瘍マーカーでは，NCC一 $\mathrm{ST} 439$ は，13U $/ \mathrm{ml}$ と軽度上显を示したが（基準值は 7.0以下), CA15-3，CEA，1CTPはいずれも正常範囲 内だった。

腹部造影 CT 検查：肝 $\mathrm{S} 6$ に径 $3 \mathrm{~cm}$ の腫場濃染像 を認めた（図 5 )。

胸部造影 CT 検查：肺野および綐隔に転移の所見は 認められなかった。

骨シンチ所見 : 第 4 腰椎に RI の集積像を認めた。

以上より，27年前の乳癌の腰椎転移および肝転移と 診断した。

治療経過：乳癌の骨転移，肝転移であることを患者 に説明し，腰椎転移に対して放射線照射 (合計 $30 \mathrm{~Gy}$ ) を行った後，化学内分泌療法を開始した（パクリタキ セル $90 \mathrm{mg}$ 毎週連続 3 週投与 1 週休薬およびアナスト ロソールによる内分泌療法)。現在治療を開始して，8

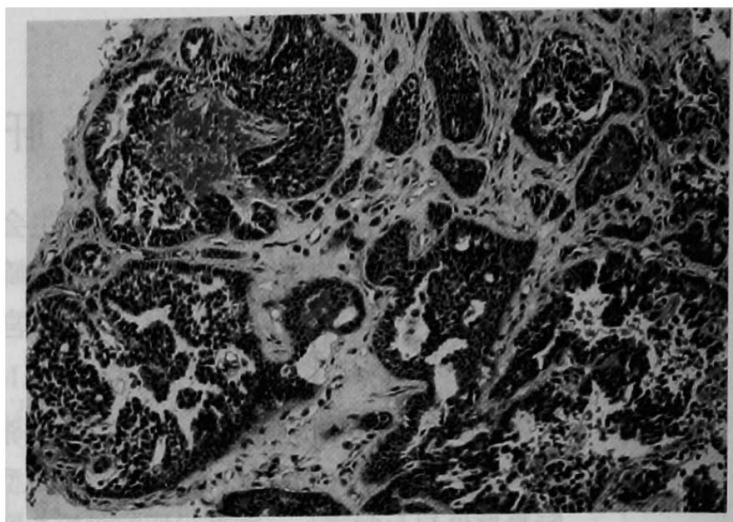

図 4 骨生検組織所見 $(\times 200, \mathrm{HE})$ ：異型上皮細胞の管胠 状, 乳頭状の增生を認め, 一部篩状構造を認める. 腺澏 の骨転移の所見である。

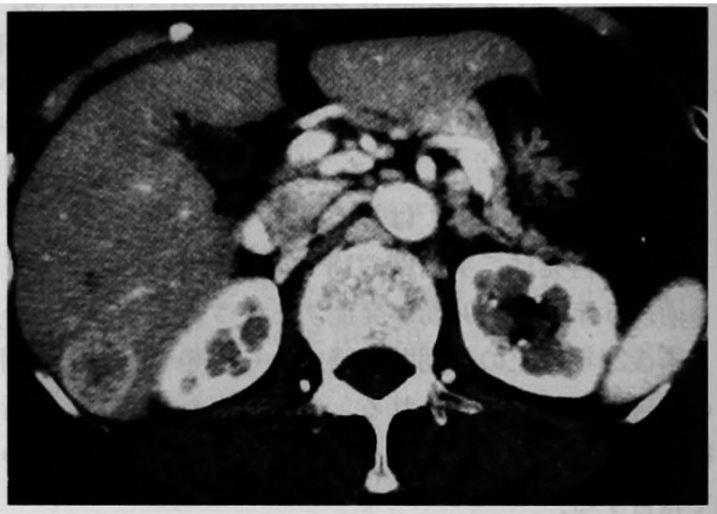

図 5 腹部造影 $\mathrm{CT}$ 検査：肝 $\mathrm{S} 6$ に径 $3 \mathrm{~cm}$ の辺縁が漢染 する SOL を認める。

カ月経過しているが，NC の状態である.

考 察

近年乳癌に対する集学的治療の進歩により乳癌の治 療成績は向上し，長期生存者が増える一方，晚期再発 の報告も頻繁にみられる。

第41回乳癌研究会の集計"1によると，乳癌再発例の 根治手術から再発までの期間は 5 年以下が $91.2 \%, 5$ 年から 10 年以下が $7.1 \% ， 10$ 年から 15 年以下が $1.1 \%$, 15 年から 20 年以下が $0.3 \% ， 20$ 年を超える症例は $0.1 \%$ であった．再発形式は，早期では局所再発が多いのに 比し，晚期再発では肺，胸膜，骨などの遠隔転移が次 第に増加傾向を示すといわれている2!.

1983年以降, 術後20年以上経過後初回再発した乳癌 の本邦報告例は，本邦を含めて29例であった（表

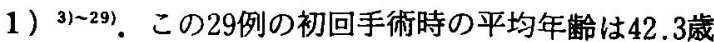


表 1 無再発期間20年以上の晩期再発乳澏の本邦報告例

\begin{tabular}{|c|c|c|c|c|c|c|}
\hline $\begin{array}{l}\text { 報告者 } \\
\text { (報告年) }\end{array}$ & $\begin{array}{l}\text { 初回手術 } \\
\text { 時年尛命 }\end{array}$ & $\begin{array}{c}\text { 再発まて } \\
\text { の期間(年) }\end{array}$ & 再発部位 & 病理組䋐所見 & 再発後治暴 & 再発後の予後 \\
\hline $\begin{array}{l}\text { 高戸 慗 } \\
\text { (1988年) }\end{array}$ & 37 & 33 & 患側胸部皮应 & 低分化型腺痁 & 切除一放射線照射 & 1 年後再発生存 \\
\hline $\begin{array}{l}\text { 今井茂樹 } \\
\text { (1990年) }\end{array}$ & 40 & 21 & 反対側鎖贯上リンパ節 & 硬瘢 & 切除， 化学内分泌撩法 & 生存 \\
\hline $\begin{array}{l}\text { 澺上 甽 } \\
(1990 \text { 年) }\end{array}$ & 41 & 24 & 患側腋䆚，患側胁骨 & 腺悹 & 切除 & 生存 \\
\hline $\begin{array}{l}\text { 太田正敏 } \\
\text { (1992年) }\end{array}$ & 43 & 30 & 患側腋曧リンパ節 & 不明 & 切除 $\rightarrow$ 放射線昭射 & 11力月無再発生存 \\
\hline $\begin{array}{l}\text { 元村和由 } \\
(1994 \text { 年) }\end{array}$ & 43 & 30 & 患側胸部皮下 & 不明 & 切除 十内分泌療法 & 1 年 8 力月無再発生存 \\
\hline $\begin{array}{l}\text { 吉村 均 } \\
\text { (1994年) }\end{array}$ & 35 & 25 & 患側胸骨上胸壁 & 充実腺管㾔 & 放射線照射 & 11年後死亡 \\
\hline $\begin{array}{l}\text { 今井茂樹 } \\
\text { (1995年) }\end{array}$ & 41 & 21 & $\begin{array}{l}\text { 反対側銷骨上 } \\
\text { リンパ節 }\end{array}$ & 硬满 & 切除 $\rightarrow$ 化学内分泌療法 & 7 年後多病死 \\
\hline $\begin{array}{l}\text { 平野鉄也 } \\
(1995 \text { 年) }\end{array}$ & 26 & 21 & 患側前胸部 & 允夷腺管棉 & 切除 & 術後約 1 年生存 \\
\hline $\begin{array}{l}\text { 深田代造 } \\
\text { (1996年) }\end{array}$ & 42 & 20 & 患側側胸部皮下 & 爯頭腺管案 & 切除 $\rightarrow$ 内分泌, 化学療法 & 生存 \\
\hline $\begin{array}{l}\text { lgarashi } \\
\text { (1998年) }\end{array}$ & 48 & 24 & 患側胸部皮店 & 硬鸒 & 放射線照射, 内分泌療法 & 2 年生存 \\
\hline $\begin{array}{l}\text { 岡田知善 } \\
(1998 \text { 年) }\end{array}$ & 59 & 20 & 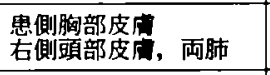 & 低分化㙞窘 & 切除 & 2 年 5 力月死亡 \\
\hline $\begin{array}{l}\text { 具志明代 } \\
\text { (1998年) }\end{array}$ & 42 & 29 & 患側胸部皮间 & 不明 & 不明 & 不明 \\
\hline $\begin{array}{l}\text { 田代英裁 } \\
\text { (1999年) }\end{array}$ & 50 & 26 & 患側胸部 & 充実腺管要 & 内分泌癔法 & 5 力月生存 \\
\hline $\begin{array}{l}\text { 松倉節子 } \\
\text { (1999年) }\end{array}$ & 40 & 42 & 患側胸部皮应 & 低分化腺潮 & 加㞠行わず & 多病死 \\
\hline $\begin{array}{l}\begin{array}{l}\text { 前原信直 } \\
(1999 \text { 年) }\end{array} \\
\end{array}$ & 39 & 29 & 患側胸膜 & 硬很 & 化学内分泌恶法 & 1 年 6 力月生存 \\
\hline $\begin{array}{l}\text { 田中一成 } \\
\text { (1999年) }\end{array}$ & 45 & 25 & 胸骨 & 乳頭腺管虞 & 化学内分泌療法 & 1 年 2 力月生存 \\
\hline $\begin{array}{l}\text { 田屟道彦 } \\
(2000 \text { 年) }\end{array}$ & 43 & 27 & 眠 & 乳頭腺管哦 & 切除 $\rightarrow$ 化学内分泌療法 & 3 年生存 \\
\hline $\begin{array}{l}\text { 黑木嘉人 } \\
\text { (2000年) }\end{array}$ & 56 & 22 & 患側前胸部皮间 & 硬茜 & 化学内行秘療法 & 3 年 1 力月後他病死 \\
\hline $\begin{array}{l}\text { 黒木嘉人 } \\
(2000 \text { 年 })\end{array}$ & 38 & 28 & 患側腋窝リンパ節 & 态実腺管癌 & 切除 $\rightarrow$ 化学内分泌療法 & 5 年 2 力月生存 \\
\hline $\begin{array}{l}\begin{array}{l}\text { 杉本 健 } \\
(2000 \text { 年) }\end{array} \\
\end{array}$ & 47 & 25 & $\begin{array}{l}\text { 患側前胸部皮店, 食道 } \\
\text { 胃, 十二指嗄，大腸 }\end{array}$ & 立実腺管癌 & 内分泌瑺法 & 1 年 9 力月死亡 \\
\hline $\begin{array}{l}\text { 藤原道久 } \\
(2000 \text { 年) }\end{array}$ & 34 & 21 & 腹膜 & 乳頭腺管癌 & 化学内分泌㞠法 & 1 年生存 \\
\hline $\begin{array}{l}\text { 香石聕男 } \\
\text { (2002年) }\end{array}$ & 36 & 25 & $\begin{array}{l}\text { 患側胸壁および腋窝り } \\
\text { シパ飾 }\end{array}$ & 不明 & $\begin{array}{l}\text { 化学缭法 } \rightarrow \text { 切除拉よび放射線 } \\
\text { 照射，化学内分泌療法 }\end{array}$ & 6 年 7 力月生存 \\
\hline $\begin{array}{l}\text { 青杨 哲 } \\
\text { (2002年) }\end{array}$ & 40 & 24 & $\begin{array}{l}\text { 患側腰部および鼠径部 } \\
\text { 皮下 }\end{array}$ & 乳頭腺管䧹 & 切除 $\rightarrow$ 内分泌治療法 & 生存 \\
\hline $\begin{array}{l}\text { 和田侥介 } \\
\text { (2002年) }\end{array}$ & 51 & 23 & 前胸壁（局所） & 乳頭腺管癌 & 化学療法 $\rightarrow$ 切除 & 5 力月生存 \\
\hline $\begin{array}{l}\text { 谷川精一 } \\
(2002 \text { 年) }\end{array}$ & 47 & $2 \overline{8}$ & 側銷骨窝リンパ節 & 髄様县 & 切除 & 1 年 6 力月生存 \\
\hline $\begin{array}{l}\text { 野見武男 } \\
(2003 \text { 年) }\end{array}$ & 46 & 28 & 膇 & 采頭腺管滛 & 切除 $\rightarrow$ 内分泌療法 & 1 年 $カ$ 力生存 \\
\hline $\begin{array}{l}\text { 石田数逸 } \\
\text { (2004年) }\end{array}$ & 44 & 31 & 患㑡鎖骨 & 不明 & 放射線照射 $\rightarrow$ 化学内分泌療法 & 約 3 年生存 \\
\hline $\begin{array}{l}\text { 直居靖人 } \\
(2004 \text { 年 })\end{array}$ & 32 & 22 & 患側腋窝，鎖骨上頚部 & 不明 & 切除 $\rightarrow$ 化学療法, 放射線照射 & 3 年 2 力月後死亡 \\
\hline 自験例 & 42 & 27 & 腰椎、肝 & 粘液癌 & 放射線照射, 化学㙩法 & 8 力月生存 \\
\hline
\end{tabular}


(26歳〜 59歳)，再発までの最長期間は，42年だった。 リンパ節郭清の有無など手術術式の詳細は不明なもの もみられたが，全例孚房全切除術がなされていた。再 発部位は局所胸壁や腋窝リンパ節などの局所再発が18 例で，遠隔転移が13例(鎖骨上㸗リンパ節：2 例, 骨： 3 例, 胸膜：1例, 肺：1 例, 腹膜：1例, 肝：1例, 脳：1例）と局所再発の方が多くみられた。初再発部 位が本例のように複数にわたつて認められたのは 7 例 であり，22例は単独再発であった。

骨転移は自験例を含めて 3 例に認められた。骨転移 の経路はほとんどが血行性転移であり，転移部位は筹 椎や骨盤など，比較的下半身の骨に生ずることが多い とされている30). 自験例は腰椎であったが，他の 2 例 は，胸骨，鎖骨と上半身の骨にみられた，骨転移に対 する治療として，2 例では放射線照射がなされ，3例 全てに化学療法（十内分泌療法）が行われていた.

晚期再発例に関する田中ら ${ }^{311}$ の検討では，無病期 5 年以上の晩期再発例は若年者にやや多く，臨床病期で は I 期が多く，ER 陽性例が多かったとされている。ま た再発部位では骨，軟部組織が多かったと報告してい る. 自験例は, 病期は I 期で ER も陽性であった。再発 部位では，20年以上の晚期再発例でみると，局所再発 の方が多くみられていた。

晚期再発を説明する乳癌の病態生理は未だ解明され ていないが, 有力な説として tumor cell dormancy と いう概念が提唱されている。これは，原発巣あるいは 転移巣において腫㕫細胞が存在しているが，何らかの 刺激があるまで潜行しているか, 非常にゆっくり成長 しているという説である ${ }^{32)}$ ，それらが増殖を開始する 誘因として，免疫状態の低下・ホルモン罢境の変化な どが想定されている。

一方, 腫瘍の発育速度は経過を通じて一定であり， 長期経過後に再発するのは初めから増殖の遅い腫湢 slow-growing tumor であるという考えがある。自験 例では，42歳時の初回発症で再発まで27年間を要して いることを考えると腫場細胞が長年 dormant stateに 留まっていたと考えるのが妥当であろう。また粘液癌 は乳癌の中では発育が緩徐で予後も比較的良好と言わ れていることも，再発が認められるまて長期間を要し た理由の一つと考えられる。

再発後の治療は，29例中16例で切除がなされ，切除 後はほとんどの症例で化学療法あるいは化学内分泌療 法がなされていた．補助療法が有効な症例が多く，再 発治療後も比較的長期生存している症例が多くみられ
た.

再発乳癌の予後は, 再発確認までの経過が長い症例 ほど,長期生存が期待できると言われ31)，また乳癌は化 学療法, 内分泌療法に感受性が高いとされており, 晩 期再発症例に対してもQOLを考慮して積極的に治療 を行うべと考える。

乳癌は進行が遅く, 術後10年以上経過してから再発 する症例がしばしばみられる。しかし実際，外来での 定期診察を 10 年以降は行わないことも多く，自験例の ように患者自身に何らかの症状が現れても，乳癌と関 係があるとは思わず，他科を受診し診断が遅れること もある.患者に対して晚期再発例もあることを説明し， 定期的な検診を行うことを啓発することが重要である と思われる。

結語

初回手術後27年で再発した乳癌の 1 例を経験したの で報告した。

謝 辞

本症例の病理診断に関し，静岡済生会総台病院臨床検查 科の星昭二先生に御指導, 御助言を賜りました.誌上にて感 謝申し上げます。

$$
\text { 文献 }
$$

1）第41回乳癌研究会：乳癌再発後生存期間に関する アンケート基本集計，日癌治療会誌 $21 ： 1167-$ 1183,1986

2）乳癌研究会 : 第28回乳癌研究会記録, 乳癌の進 展・再発を左右する因子、日癌治療会誌 $14: 952$ $-959,1979$

3）高戸 毅, 征矢野進一, 大久保栄治他: 乳癌術後, 長期経過して局所再発を生じた 2 例. 形成外科 $31: 815-819,1988$

4）今井茂樹, 宗盛 修, 小牧久和子他：乳癌術後24 年目に骨転移の出現した 1 症例。骨転移 $7: 57$ $-60,1990$

5）滝上 剛, 石田宏文, 清水鉄也他：初回手術後24 年目に再発を来たした乳癌の1例。道南医会誌 $25: 108-110,1990$

6) 太田正敏, 杉原 隆, 向井正哉他：術後30年目に 腋窝リンパ節再発をきたした乳癌の 1 例. 日臨外 医会誌 $53: 571-575,1992$

7）元村和由, 野口椇三郎, 稲治英生 他：術後30年目 に局所再発をきたした乳癌の 1 例. 日臨外医会誌 $55: 2247-2249,1994$

8）吉村 均, 玉田敏明, 岩田和朗 他：放射線 - 手術 
併用治療により長期生存した乳癌術後晚期胸壁再

発の 1 例。乳癌の臨 $9: 694-699$, 1994

9）今井茂樹，暒原康正，宗盛修他：晚期再発乳癌 食道転移の 1 例。乳癌の臨 $10: 197-202,1995$

10）平野鉄也, 古山裕章, 川上義行他：術後21年目に 局所再発をきたした乳密の 1 切除例。外科 57 ： 993-995, 1995

11）深田代造, 鹰尾博司, 佐治重豊他：根治術後20年 目に局所再発をきたした乳癌の 1 例. 癌の臨 42 : 639-64:2, 1996

12) Igarashi $T$, Itoh $K, F u j i i ~ H$, et al : Successful treatment by radiation and hormone therapy of isolated local recurrence of breast cancer 24 years after mastectomy accompanied by immune thrombocytopenia : a case report. Jpn $\mathrm{J}$ Clin Oncol $28: 270-275,1998$

13）岡田知善, 原 弘之, 桶井史典他：20年後に生じ た乳癌の Delayed Cutaneous Metastases. 西日 皮 $60: 643-647,1998$

14）具志明代, 内宮礼嗣, 瀬戸山充他：29年後に手術 没痕部に再発した乳癌の 1 例. 皮眉臨床 40 ： $1504-1505,1998$

15）田代英哉, 増野浩二郎, 久米一弘地：乳房切除術 から26年後に局所再発した乳癌の生物学的特徽.

乳窝の臨 $14: 251-254,1999$

16）松倉節子, 昖本真純, 高橋一夫：秏揘手術 42 年後 に出現した delayed cutaneous metastasis $の 1$ 例. 臨皮 $53: 113-115,1999$

17）前原信直, 今井茂樹, 梶原康正他: 術後29年で再 発した乳癌胸膜転移の1例. 乳癌の臨 $14: 405-$ 408,1999

18）田中一成, 杉下岳夫, 児玉 倰他: 乳癌根治手術 後25年を経て骨転移再発をきたした 1 例. 日臨外 会誌 $60: 2069-2071,1999$

19）田尻道彦, 酒向晃弘, 石井治彦他: 乳癌術後27年 に発症した肺転移巣を胸腔鏡下に切除した 1 例. 胸部外科 $53: 242-245,2000$

20）黒木嘉人, 楾年宏, 坂本隆他: Medroxy- progesterone acetate が著奻を示した術後22年目 と28年目の再発乳癌の 2 例. 日臨外会誌 $61: 62$ $-6 \overline{5}, 2000$

21）杉本 健, 白川京佐, 堀尾嘉昭他：術後25年目に 発症した乳癌の食道・胃・十二指腸・大腸転移の 1 例. 胃と腸 $35: 1313-1319 ， 2000$

22) 藤原道久, 河本義之, 物部泰昌他：乳癌術後21年 目に癌性腹膜炎を発症した 1 例. 川崎医会誌 $26: 155-159,2000$

23）白石憲男, 中村 彰, 垣迫健二他：長期経過後に 再発した乳癌の 8 例. 日臨外会誌 $63: 853-856$, 2002

24）青柳 哲, 加藤直子：乳癌術後24年後に生じた delayed cutaneous metastasis $の 1$ 例. Skin Cancer 17:166-169, 2002

25）和田俊介，富田雅樹，松崎泰慧他：乳癌手術後23 年目に胸壁再発をきたした 1 例. 宮崎医師会誌 $26: 168-170,2002$

26）谷川精一：乳がん根治術後28年目に鎖骨リンパ節 に転移をきたした 1 例.山口医会誌 $36 ： 9-12$ ， 2002

27）野見武男，中辻直之，杉原誠一他：術後28年目に 脑転移をきたした乳癌の1例. 日臨外会誌 64 ： 3014-3018, 2003

28）石田数逸，大谷弘樹，福原抬治他：術後31年目に 骨転移をきたした孚雷の1例。愛媛医 $23: 188$ 一 191, 2004

29）直居靖人，山本 仁，黒川英司：術後22年乳癌晚 期再発の 1 例. 日外科系連会誌 $29: 731-734$, 2004

30) Batson $\mathrm{OV}:$ The vertebral vein system. Am J Roentgenol $78: 195-212,1957$

31）田中規文，高塚雄一，河原勉他：乳癌晚期再発 例の挨討. 日臨外医会誌 $49: 2248-2251 ， 1988$

32) Demicheli R, Terenziani M, Valagussa $P$, et al : Local recurrences following mastectomy : support for the concept of tumor dormancy. J Natl Cancer Inst $86: 45-48.1994$ 


\title{
A CASE OF BREAST CANCER WITH METASTASIS TO THE BONE AND THE LIVER 27 YEARS AFTER A MASTECTOMY
}

\author{
Toru MURATA, Masaki TERASAKI, Kenji SAKAGUCHI, \\ Masayuki OKUBO, Yuji SHINGU and Yasuyuki FUKAMI \\ Department of Surgery, Shizuoka Saiseikai General Hospital
}

We report a case of a recurrence of a breast cancer 27 years after operation. A 69-year-old woman with lumbago, who underwent a standard radical mastectomy at the age of 42 , consulted the orthopedics department of our hospital. Since she was suspected to have a pathological fracture of the lumbar vertebra, a bone biopsy guided by computed tomography was performed. Histological examination revealed a case of adenocarcinoma metastasizing to the vertebra. Gynecological and gastrointestinal examinations could not reveal any possible primary lesion of the metastasis. Then the patient was referred to our department, where immunostaining of the biopsy specimen with anti-estrogen receptor antibody was done with positive result. Therefore, the patient was diagnosed as having a metastatic vertebral tumor of breast cancer, which occurred 27 years postoperatively. An abdominal computed tomogram demonstrated metastatic lesion in the liver also measuring $3 \mathrm{~cm}$ in diameter. She received radiation therapy for the vertebral metastasis followed by systemic chemoendotherapy with Paclitaxel and Anastrozole. There observed no changes in the size of the metastases at this writing. 